\title{
Adaptive Market Hypothesis
}

\author{
Submitted 23/06/19, $1^{\text {st }}$ revision $18 / 07 / 19,2^{\text {nd }}$ revision $11 / 10 / 19$, accepted $05 / 11 / 19$
}

\author{
Pınar Evrim Mandacı ${ }^{1 *}$, F. Dilvin Taşkın², Zeliha Can Ergün ${ }^{3}$ \\ Abstract:
}

Purpose: To investigate the implications of the Addaptive Market Hypothesis (AMH) on Turkish stock exchange market (Borsa Istanbul) indices as an emerging economy. BIST-100, BIST-30 and BIST-All indices are subjected to the analyses for the period between January 2002 and April 2017.

Design/Methodology/Approach: Two-year rolling windows and daily test values were calculated by using linear methods (Variance Ratio Test) and nonlinear methods (BDS test) to investigate the market efficiency.

Findings: According to the Variance Ratio Test results, index returns are unpredictable, that is, the market is efficient, while the results of nonlinear analysis show the existence of adaptive market hypothesis. In particular, all three indices display efficiency in the 2013-2016 period implying that returns were not predictable in this period. The results of the non-linear analysis show that the market is efficient from time to time and sometimes deviates from efficiency, indicating the validity of the adaptive market hypothesis in Borsa Istanbul.

Practical Implications: The changes in the market efficiency from time to time should be considered while taking important investment decisions. Moreover, according to AMH, since trends, panics, bubbles and crashes exist in the market, arbitrage opportunities arise time to time, and market timing is an important issue to catch the profit opportunities. Therefore, as a further study, matching the important events with the efficiency of the market could provide more insights about timing the market.

Originality/Value: To the best of authors' knowledge, this is the first comprehensive study that examines the index based AMH in Borsa Istanbul. This study is believed to contribute to the literature by giving insights about the evolution of market efficiency in Turkey.

\footnotetext{
${ }^{1}$ Professor, Department of Business Administration, Faculty of Business, Dokuz Eylul University, pinar.evrim@deu.edu.tr

${ }^{2}$ Associate Professor, Department of Business Administration, Faculty of Business, Yaşar University,dilvin.taskin@yasar.edu.tr

${ }^{3}$ Research Assistant Dr., Department of International Trade and Business, Faculty of Business, Adnan Menderes University, zeliha.can@adu.edu.tr

* The author contributed to this study while conducting research as visiting professor at University at Albany (SUNY), Center for Institutional Investment Management, Massry Center for Business, Massry Center for Business' Room 3631400 Washington Avenue, Albany, NY.
} 
Keywords: Adaptive Market Hypothesis, Efficient Market Hypothesis, Behavioral Finance, Stock Markets, Market Efficiency.

JEL Codes: G1, G40, G41.

Article Type: Research study.

\section{Introduction}

The Efficient Market Hypothesis (EMH), which is developed by Fama (1970), asserts that stocks in the market reflect all the relevant and available information and the current prices reflect their fundamental values. Based on the EMH prices follow "random walk", thus the changes are unpredictable and random. Therefore, investors cannot produce superior returns over time. As emphasized by Grossman and Stiglitz (1980) investors are willing to spend time and resources to search for new information only if it is worth to do that and, only in these conditions, they may provide higher investment returns. Fama (1970) introduced three forms of market efficiency: weak, semi-strong and strong forms while the degree of efficiency varies across different markets. The EMH has been discussed by many researchers and practitioners for a long time, and the debate is still ongoing, and it continues to prepossess many researchers (Bodie, Kane and Marcus, 2014). However, recently, behavioral finance has started to deal with how rational the practitioners and how efficient the markets are.

Particularly, behavioral finance criticizes the three assumptions of the EMH (Shleifer, 2000). First, according to the EMH all the investors are rational, and the security valuation is done rationally. However, in reality, the incentives, emotions and biases of the investors have an effect on their decision-making process, but classical finance ignores it (Barberis and Thaler, 2003). Second, although there are some irrational investors (or noise traders) in the market, according to the EMH their trades are random and accordingly could cancel each other, so the influence of these noise traders to the market is not distinctive. However, according to the behavioral finance investors make decisions with heuristics and consequently biases occur. Last, the EMH defends that rational arbitrageurs in the market could eliminate the influence of irrational investors, because they act in similar ways. Contrarily, according to the behavioral finance since the number of rational arbitrageurs are limited in the market, they are insufficient to force prices to match fundamental value (Bodie, Kane and Marcus, 2010).

The followers of EMH often criticized the ideas of behavioral finance for being primarily observational and not containing any principles to explain their counter examples (Lo, 2005). On the other hand, the EMH literature is also criticized by the behavioral finance proponents for using market efficiency as an all-or-nothing case rather than considering it to evolve over time (Ghazani and Araghi, 2014). Based on these criticisms Lo $(2004 ; 2005)$ suggests a new paradigm that consolidates the EMH 
with behavioral biases and bounded rationality, he calls it Adaptive Market Hypothesis (AMH). Under the AMH the market efficiency is not an all-or-nothing case, instead Lo (2004) suggests that efficiency varies over time and across markets due to the changing market conditions such as bubbles, crashes and crises, thus the market efficiency is defined as being a highly context-dependent and dynamic, and it is derived from evolutionary principles (Lo, 2004). As emphasized by Lim and Brooks (2011) the supported ideas of AMH are based on the several bodies of literature containing evolutionary biology, evolutionary psychology, behavioral ecology, bounded rationality of economics and complex systems. Particularly, the competition, mutation, reproduction and natural selection principles of evolutionary biology is thought to constitute the underlying determinants of market efficiency and impact the waxing and waning of businesses, industries and financial products (Lo, 2005).

There are several components of AMH that contradicts with the EMH. First, according to the EMH, market is always in equilibrium and stationary, so investors are not exposed to learning and adaptation process and they do not make any mistakes. However, AMH supports that although investors act in their own self-interest, they often make mistakes, and they learn from these mistakes and adapt their behavior (Lo, 2005).

Second, AMH argues that natural selection has an important role in shaping market participants. For example, if the investors experienced losses in their previous investments, they are more likely to leave the market (Lo, 2004).

Third, contrary to the EMH, AMH states that since trends, panics, bubbles and crashes exist in the market, arbitrage opportunities arise time to time, and market timing is an important issue to catch the profit opportunities. Similarly, the profitability of investment strategies may also temporarily increase or decrease due to environmental conditions (Lo, 2004). Finally, the AMH suggests that stock market environment and demographics of the investors shape the risk/reward relation, and the risk premium varies over time (Lo, 2004). In sum, these ideas of the AMH defend that the market efficiency may evolve over time depended on the market conditions.

The main aim of this study is to investigate the implications of the AMH on Turkish stock exchange market (Borsa Istanbul) as an emerging economy. BIST-100, BIST30 and BIST-All indices are subjected to the analyses for the period between January 2002 and April 2017. To the best of authors' knowledge, this is the first comprehensive study that examines the index based AMH in Borsa Istanbul . This study is believed to contribute to the literature by giving insights about the evolution of market efficiency in Turkey.

The rest of the paper is structured as follows: the second part explains the related literature, the third part will provide information about the methodology, the fourth part will include the results of the analysis and the last part will conclude the study. 


\section{Literature Review}

In the literature, two approaches are used to examine Adaptive Market Hypothesis $(\mathrm{AMH})$. The first one that analyzes market efficiency is the "time-varying model" approach (Ito, Noda and Wada 2014; 2016). In these studies, it is concluded that the degree of market efficiency varies over time. The second approach explores market efficiency using statistical tests based on the "moving window" method (Lo, 2004; Kim, Shamsuddin and Lim, 2011; Lim, Luo and Kim, 2013). Some of these methods are the automatic variance ratio test of Choi (1999), the automatic portmanteau test of Escanciano and Lobato (2009) and the generalized spectral test of Escanciano and Velasco (2006).

The studies related to AMH are both for developed (Lo, 2004; Kim, Shamsuddin and Lim, 2011; Lim, Luo and Kim, 2013; Urquhart and Hudson, 2013; Urquhart, Gebka and Hudson, 2015; Noda, 2016; Urquhart and McGroaty, 2016) and developing country stock markets (Lim, 2007; Todeo, Ulici and Silaghi, 2009; Popovic Mugosa and Durovic, 2013; Dyakova and Smith, 2013a; Hiremath and Kumari, 2014; Gyamfi, 2018; Thalassinos et al., 2015). There are also studies addressing both markets together (Lim and Brooks, 2006; Lim, 2007; Smith 2012). The studies that deal with the Turkish stock market together with many other developed and developing markets include Dyakova and Smith (2013b), Niemczak and Smith (2013) Hull and McGroarty (2014). In addition, Ertaş and Özkan (2018) evaluate the monthly returns of both BIST-100 and S\&P 500 indices between 01.02.1988 and 01.02.2018 and utilize the rolling window method used in Lo (2004). As a result of these studies, the efficiency of the Turkish stock market changes over time and these results are in line with the AMH.

Studies on AMH do not only focus on stock markets but also foreign exchange markets (Neely, Weller and Ulrich, 2009; Charles, Darne and Kim, 2012) commodity markets (Ghazani and Ebrahimi, 2019) Real Estate Investment Trusts (REIT) (Zhou and Lee, 2013) and Crypto currencies (Khuntia and Pattanayak, 2018). However, since the Turkish stock market is discussed in this study, only the studies dealing with stock markets are examined in the literature and presented in a table. As can be seen from Table 1, almost all of the studies dealing with AMH strongly prove that stock return behaviors are consistent with AMH.

Table 1. Studies on AMH

\begin{tabular}{|l|l|l|}
\hline Study & Data and Methodology & Results \\
\hline Lo (2004) & $\begin{array}{l}\text { Monthly returns of the S\&P } \\
\text { Composite index during the period } \\
\text { of 1871-2003 are analyzed over 5- } \\
\text { year rolling window. }\end{array}$ & $\begin{array}{l}\text { The degree of market } \\
\text { efficiency varies cyclically } \\
\text { over time. }\end{array}$ \\
\hline $\begin{array}{l}\text { Lim and Brooks } \\
(2006)\end{array}$ & $\begin{array}{l}\text { Daily returns of MSCI indices of 23 } \\
\text { developed and 27 developing } \\
\text { countries from December 31, 1989 to }\end{array}$ & $\begin{array}{l}\text { The degree of market } \\
\text { efficiency } \\
\text { periodically over time. The }\end{array}$ \\
\hline
\end{tabular}




\begin{tabular}{|c|c|c|}
\hline & $\begin{array}{l}\text { December } 31,2005 \text { are analyzed } \\
\text { with the help of portmanteau bi- } \\
\text { correlation test statistics of Hinich } \\
\text { (1996) in a rolling sample approach. }\end{array}$ & $\begin{array}{l}\text { results obtained are } \\
\text { consistent with the AMH. }\end{array}$ \\
\hline $\begin{array}{l}\text { Self and Mathur } \\
(2006)\end{array}$ & $\begin{array}{l}\text { Daily returns of the stock indices of } \\
\text { G- } 7 \text { countries during the period of } \\
1992-2003 \text { are analyzed using } \\
\text { MTAR model and E-G stationary } \\
\text { tests. }\end{array}$ & $\begin{array}{l}\text { Revealed existence of } \\
\text { symmetric stationary } \\
\text { periods, abnormal market } \\
\text { behaviors emerge and } \\
\text { market efficiency changes } \\
\text { over time. }\end{array}$ \\
\hline Lim (2007) & $\begin{array}{l}\text { Daily returns of } 11 \text { developing } \\
\text { (Argentina, Brazil, Chile, Indonesia, } \\
\text { Malaysia, Mexico, Philippines, } \\
\text { South Korea, Taiwan and Thailand) } \\
\text { and } 2 \text { developed countries (Japan } \\
\text { and USA) for the period from } \\
\text { January } 1992 \text { to December } 2005 \text {, are } \\
\text { analyzed by using rolling sample } \\
\text { portmanteau bi-correlation test } \\
\text { statistic over a rolling window of } 50 \\
\text { observations. }\end{array}$ & $\begin{array}{l}\text { Each market's level of } \\
\text { efficiency evolves over } \\
\text { time in a way consistent } \\
\text { with the AMH. }\end{array}$ \\
\hline $\begin{array}{l}\text { Todeo, Ulici and } \\
\text { Silaghi (2009) }\end{array}$ & $\begin{array}{l}\text { The daily returns of the stock market } \\
\text { indices of } 6 \text { Asian countries (Hang- } \\
\text { Seng, BSSE, Kuala Lumpur, Strait } \\
\text { Times and Nikkei 225) during the } \\
\text { period of 1997-2008 are analyzed } \\
\text { using the moving average strategy. }\end{array}$ & $\begin{array}{l}\text { Profit opportunities are not } \\
\text { constant over time, so the } \\
\text { degree of market efficiency } \\
\text { changes periodically over } \\
\text { time. The results obtained } \\
\text { support AMH. }\end{array}$ \\
\hline $\begin{array}{l}\text { Ito and Sugiyama } \\
(2009)\end{array}$ & $\begin{array}{l}\text { Monthly returns of S\&P } 500 \text { index } \\
\text { during the period of January } 1955- \\
\text { February } 2006 \text { are used to calculate } \\
\text { first-order auto-correlations by } \\
\text { applying rolling window approach. }\end{array}$ & $\begin{array}{l}\text { The degree of market } \\
\text { efficiency varies over time } \\
\text { with the market being most } \\
\text { inefficient during the late } \\
\text { 1980s and most efficient } \\
\text { around the year 2000. }\end{array}$ \\
\hline $\begin{array}{l}\text { Kim, Shamsuddin } \\
\text { and Lim (2011) }\end{array}$ & $\begin{array}{l}\text { Daily returns of DJIA during the } \\
\text { period of } 1900-2009 \text { are analyzed } \\
\text { using automatic variance ratio, } \\
\text { automatic portmanteau and } \\
\text { generalized spectral tests. }\end{array}$ & $\begin{array}{l}\text { The degree of market } \\
\text { efficiency varies } \\
\text { periodically over time. }\end{array}$ \\
\hline $\begin{array}{l}\text { Alvarez-Ramirez, } \\
\text { Rodriguez and } \\
\text { Espinosa-Paredes } \\
(2012)\end{array}$ & $\begin{array}{l}\text { The daily returns of the DJIA from } \\
1929 \text { to March } 2012 \text { are used to } \\
\text { compute the fractional scaling } \\
\text { exponent from the detrended } \\
\text { fluctuation analysis (DFA), } \\
\text { implemented over a rolling window. }\end{array}$ & $\begin{array}{l}\text { Parallel to the AMH, market } \\
\text { efficiency may change over } \\
\text { time. }\end{array}$ \\
\hline Smith (2012) & $\begin{array}{l}\text { Daily returns of } 15 \text { developing and } 3 \\
\text { developed countries in Europe from } \\
\text { February } 2000 \text { to December } 2009 \text { are }\end{array}$ & $\begin{array}{l}\text { Turkey, U.K, Hungary and } \\
\text { Poland are the most } \\
\text { efficient markets on the } \\
\text { other hand; Ukraine, Malta }\end{array}$ \\
\hline
\end{tabular}




\begin{tabular}{|c|c|c|}
\hline & $\begin{array}{l}\text { examined using rolling window } \\
\text { variance test ratio. }\end{array}$ & $\begin{array}{l}\text { and Estonia are the least } \\
\text { efficient markets. Each of } \\
\text { the } 18 \text { markets shows } \\
\text { evidence of the time- } \\
\text { varying nature of return that } \\
\text { is consistent with AMH. }\end{array}$ \\
\hline $\begin{array}{l}\text { Lim, Luo and Kim } \\
\text { (2013) }\end{array}$ & $\begin{array}{l}\text { Daily returns of the U.S. indices } \\
\text { namely DJIA, S\&P } 500 \text { and NYSE } \\
\text { Composite price indices between } \\
\text { December } 31,1969 \text { and December } \\
31,2008 \text { are analyzed using } \\
\text { automatic portmanteau Box-Pierce } \\
\text { test and boothstrapped automatic } \\
\text { variance ratio test through a rolling } \\
\text { estimation approach. }\end{array}$ & $\begin{array}{l}\text { Return predictability varies } \\
\text { over time and those periods } \\
\text { with significant return } \\
\text { autocorrelations can be } \\
\text { largely associated with } \\
\text { major exogenous events, } \\
\text { thus consistent with AMH. }\end{array}$ \\
\hline $\begin{array}{l}\text { Popovic Mugosa } \\
\text { and Durovic (2013) }\end{array}$ & $\begin{array}{l}\text { Daily and weekly returns of the } \\
\text { Montenegrin stock market from } \\
\text { January 3, } 2004 \text { to December } 31 \text {, } \\
2011 \text { are analyzed using the rolling } \\
\text { window approach. }\end{array}$ & $\begin{array}{l}\text { Market efficiency varies } \\
\text { over time. }\end{array}$ \\
\hline $\begin{array}{l}\text { Urquhart and } \\
\text { Hudson (2013) }\end{array}$ & $\begin{array}{l}\text { The daily returns of DJIA, FT } 30 \text { and } \\
\text { TOPIX indices from the date of their } \\
\text { first publication until } 31 \text { December } \\
2009 \text { are examined by dividing data } \\
\text { into 5-year sub-samples and } \\
\text { employing linear (autocorrelation, } \\
\text { running and variance ratio tests) and } \\
\text { non-linear methods (McLeod Li, } \\
\text { Engle LM and BDS tests). }\end{array}$ & $\begin{array}{l}\text { The linear tests seem to } \\
\text { support AMH, but } \\
\text { nonlinear tests show that } \\
\text { markets remain inefficient } \\
\text { even if time changes. }\end{array}$ \\
\hline $\begin{array}{l}\text { Dyakova and Smith } \\
\text { (2013a) }\end{array}$ & $\begin{array}{l}\text { Daily observations on SOFIX and } \\
\text { BG } 40 \text { stock price indices and the } \\
\text { prices of } 8 \text { individual stocks traded in } \\
\text { the Bulgarian Stock Market during } \\
\text { the period of } 20 \text { October } 2000-31 \\
\text { August } 2012 \text { are analyzed using } \\
\text { finite-sample variance ratio tests in a } \\
\text { rolling window. }\end{array}$ & $\begin{array}{l}\text { Parallel to } \mathrm{AMH} \text {, the level } \\
\text { of predictability of returns } \\
\text { may change. }\end{array}$ \\
\hline $\begin{array}{l}\text { Dyakova and Smith } \\
\text { (2013b) }\end{array}$ & $\begin{array}{l}\text { Daily returns of } 40 \text { Bulgarian stocks, } \\
2 \text { Bulgarian stock market indices and } \\
\text { stock market indices of } 13 \text { other } \\
\text { European countries including } \\
\text { Turkey, during the period of } \\
\text { February } 72005-31 \text { August } 2012 \text {, } \\
\text { are examined by using three finite } \\
\text { sample variance ratio test (Joint sign, } \\
\text { Wild-bootstrap and automatic } \\
\text { variance ratio tests). }\end{array}$ & $\begin{array}{l}\text { The return predictability of } \\
\text { both stock and stock market } \\
\text { indices changes } \\
\text { dramatically over time. }\end{array}$ \\
\hline
\end{tabular}




\begin{tabular}{|c|c|c|}
\hline $\begin{array}{l}\text { Niemczak and } \\
\text { Smith (2013) }\end{array}$ & $\begin{array}{l}\text { Daily returns of the } 11 \text { Middle East } \\
\text { country stock markets including } \\
\text { Turkey between February 1, } 1999 \\
\text { and December } 1,2010 \text { are analyzed } \\
\text { by using Wild-Boothstrap and } \\
\text { automatic variance ratio tests. }\end{array}$ & $\begin{array}{l}\text { Most markets experience } \\
\text { successive periods of } \\
\text { efficiency and inefficiency, } \\
\text { consistent with AMH. } \\
\text { Among these markets the } \\
\text { least predictable (the most } \\
\text { efficient) ones are Turkey, } \\
\text { Egypt and Israel; the most } \\
\text { predictable (the least } \\
\text { efficient) ones are Jordan, } \\
\text { Lebanon and Saudi Arabia. }\end{array}$ \\
\hline $\begin{array}{l}\text { Hull and McGroarty } \\
\text { (2014) }\end{array}$ & $\begin{array}{l}\text { Daily returns of } 22 \text { emerging markets } \\
\text { including Turkey during the period } \\
\text { of June, } 301995-30 \text { June, } 302011 \\
\text { are examined by employing Hurst- } \\
\text { Mandelbrot-Wallis rescaled range } \\
\text { test. }\end{array}$ & $\begin{array}{l}\text { There is strong evidence to } \\
\text { support AMH. }\end{array}$ \\
\hline $\begin{array}{l}\text { Ghazani and Araghi } \\
\text { (2014) }\end{array}$ & $\begin{array}{l}\text { The daily returns of TEPIX index in } \\
\text { Tehran Stock Exchange between } \\
\text { March 28, } 1999 \text { and March 18, } 2013 \\
\text { are analyzed using linear (automatic } \\
\text { variance ratio and automatic } \\
\text { portmanteau) and nonlinear } \\
\text { (generalized spectral and McLeod- } \\
\text { Li) tests. }\end{array}$ & $\begin{array}{l}\text { In line with the AMH, } \\
\text { market efficiency varies } \\
\text { over time. }\end{array}$ \\
\hline $\begin{array}{l}\text { Rodriguez, Aguilar- } \\
\text { Cornejo and } \\
\text { Alvarez-Ramirez } \\
(2014)\end{array}$ & $\begin{array}{l}\text { The daily returns of the DJIA index } \\
\text { from } 1929 \text { to March } 2014 \text { are } \\
\text { analyzed using detrended fluctuation } \\
\text { analysis (DFA). }\end{array}$ & $\begin{array}{l}\text { In line with the AMH, } \\
\text { market effectiveness varies } \\
\text { from week to year } \\
\text { according to different time } \\
\text { scales. }\end{array}$ \\
\hline $\begin{array}{l}\text { Smith and Dyakova } \\
\text { (2014) }\end{array}$ & $\begin{array}{l}\text { The daily stock price indices for } 8 \\
\text { African stock markets from February } \\
2,1998 \text { to December } 30,2011 \text { are } \\
\text { analyzed using rolling window } \\
\text { analysis on three finite-sample } \\
\text { variance ratio tests. }\end{array}$ & $\begin{array}{l}\text { The predictability of return } \\
\text { on country indices changes } \\
\text { over time. Egypt, South } \\
\text { Africa and Tunisia have a } \\
\text { minimum predictability; } \\
\text { Kenya, Zambia and Nigeria } \\
\text { are the most predictable } \\
\text { countries. }\end{array}$ \\
\hline $\begin{array}{l}\text { Hiremath and } \\
\text { Kumari (2014) }\end{array}$ & $\begin{array}{l}\text { Daily returns of Sensex index } \\
\text { between January 1991-March } 2003 \\
\text { and Nifty index between January } \\
\text { 1994-March } 2013 \text { traded in India are } \\
\text { analyzed by using linear } \\
\text { (autocorrelation, runs, variance ratio } \\
\text { and multiple variance ratio) and } \\
\text { nonlinear (McLeod Li, Tsay, } \\
\text { ARCH-LM, portmanteau and BDS) } \\
\text { tests. }\end{array}$ & $\begin{array}{l}\text { The findings of linear tests } \\
\text { support the cyclical pattern } \\
\text { between efficiency and } \\
\text { inefficiency, while the } \\
\text { results of non-linear tests } \\
\text { suggest varying degrees of } \\
\text { non-linearity. }\end{array}$ \\
\hline
\end{tabular}




\begin{tabular}{|c|c|c|}
\hline $\begin{array}{l}\text { Urquhart, Gebka } \\
\text { and Hudson (2015) }\end{array}$ & $\begin{array}{l}\text { Daily returns of the DJIA index of } \\
\text { the U.S., the FT30 index of the U.K } \\
\text { and TOPIX index of Japan between } \\
\text { January } 1,1987 \text { and December } 31 \text {, } \\
2013 \text { are analyzed using the moving } \\
\text { average. }\end{array}$ & $\begin{array}{l}\text { Investors can make high } \\
\text { profits by trading on } \\
\text { anticipating signals; } \\
\text { suggesting that investors } \\
\text { are anticipating signals in a } \\
\text { way consistent with the } \\
\text { AMH. }\end{array}$ \\
\hline $\begin{array}{l}\text { Hiremath and } \\
\text { Narayan (2016) }\end{array}$ & $\begin{array}{l}\text { Daily returns of Sensex and Nifty } \\
\text { indices of Indian stock market } \\
\text { between January 1991and December } \\
2013 \text { are analyzed by employing } \\
\text { generalized Hurst exponent, derived } \\
\text { using fixed and rolling windows. }\end{array}$ & $\begin{array}{l}\text { The Indian stock market has } \\
\text { evolved over a period of } \\
\text { time and has progressed } \\
\text { towards becoming efficient. } \\
\text { The degree of efficiency is } \\
\text { higher during the financial } \\
\text { crisis, when the Indian } \\
\text { stock market is vulnerable } \\
\text { to external shocks. }\end{array}$ \\
\hline $\begin{array}{l}\text { Ito, Noda and Wada } \\
\text { (2016) }\end{array}$ & $\begin{array}{l}\text { Monthly returns of S\&P } 500 \text { index } \\
\text { during the period of January } 1871 \text { - } \\
\text { December } 2012 \text { are used to develop } \\
\text { a non-Bayesian time-varying model } \\
\text { (time-varying autoregressive model- } \\
\text { TV-AR). }\end{array}$ & $\begin{array}{l}\text { The U.S. stock market has } \\
\text { evolved over time } \\
\text { consistent with AMH. }\end{array}$ \\
\hline Nod & $\begin{array}{l}\text { The monthly returns of Japan's } \\
\text { TOPIX and TSE2 indices for the } \\
\text { period from October } 1961 \text { to } \\
\text { December } 2015 \text { are analyzed using } \\
\text { the time-varying model approach as } \\
\text { in the studies of Ito, Noda and Wada } \\
(2014,2016) \text {. }\end{array}$ & $\begin{array}{l}\text { The efficiency of both } \\
\text { markets changes over time. } \\
\text { The TOPIX index is more } \\
\text { efficient than the TSE2 } \\
\text { index. The efficiency of } \\
\text { TOPIX market, which is a } \\
\text { more qualified index, is } \\
\text { changing and TSE2 index } \\
\text { does not change. } \\
\text { Accordingly, the results } \\
\text { obtained support AMH. }\end{array}$ \\
\hline $\begin{array}{l}\text { Urquhart and } \\
\text { McGroaty (2016) }\end{array}$ & $\begin{array}{l}\text { Daily returns of the S\&P 500, FTSE } \\
\text { 100, NIKKEI } 225 \text { and EURO } \\
\text { STOXX } 50 \text { indices during the period } \\
\text { of January 1990-May } 2014 \text { are } \\
\text { analyzed using three bootstrapped } \\
\text { versions of the variance ratio test and } \\
\text { nonlinear BDS test. }\end{array}$ & $\begin{array}{l}\text { The predictability of return } \\
\text { on stock exchanges changes } \\
\text { over time consistent with } \\
\text { AMH. Each market adapts } \\
\text { differently to certain market } \\
\text { conditions. }\end{array}$ \\
\hline Gyan & $\begin{array}{l}\text { Daily returns of the GSEALSH and } \\
\text { GSEFSII indices in the Ghana stock } \\
\text { market between January } 4,2011 \text { and } \\
\text { August } 28,2015 \text { are analyzed using } \\
\text { generalized spectral test, automatic } \\
\text { portmanteau BOX-Pierce test and } \\
\text { Wild-Bootstrapped automatic } \\
\text { variance ratio tests. A rolling }\end{array}$ & $\begin{array}{l}\text { In all three tests, the } \\
\text { GSEALSH index is more } \\
\text { predictable than the other. } \\
\text { The results obtained are } \\
\text { consistent with AMH. }\end{array}$ \\
\hline
\end{tabular}




\begin{tabular}{|l|l|l|}
\hline & $\begin{array}{l}\text { window approach is used to track } \\
\text { whether returns are predictable or } \\
\text { not through time. }\end{array}$ & \\
\hline $\begin{array}{l}\text { Ertaş and Özkan } \\
(2018)\end{array}$ & $\begin{array}{l}\text { Monthly returns of BIST-100 and } \\
\text { S\&P 500 indices for the period from } \\
\text { February 1, 1988 to February 1, 2018 } \\
\text { are examined using the 5-year rolling } \\
\text { window method as in Lo (2004). }\end{array}$ & $\begin{array}{l}\text { The efficiencies of these } \\
\text { markets are differentiating } \\
\text { over time. In explaining the } \\
\text { behavior of these two } \\
\text { markets, AMH is more } \\
\text { successful than the Efficient } \\
\text { Market Hypothesis. }\end{array}$ \\
\hline
\end{tabular}

\section{Methodology}

We used a linear and a non-linear tests namely variance ratio test and BDS test to appraise the predictability of returns. These tests enable to detect the dependency of the returns, thus will enable us to conclude about the efficiency of the market. The test statistics that point to fluctuations between dependency and independency of the returns will be an indication of the AMH and the inefficiency of the market.

\subsection{Variance Ratio Test}

Variance ratio test (VR) which was developed by Lo and MacKinlay (1988), is one of the fundamental tests to detect the correlation between stock return series. VR test assume that in order for a series to follow random walk, the variance of the k-period return should be equal to $\mathrm{k}$ times the variance of the one period return. Let $r_{t}$ denote the one-period return at time $t$, then the variance ratio for $r_{t}$ with a holding period of $k$ is

$V R(K)=1+2 \sum_{j=1}^{k-1}\left(1-\frac{j}{k}\right) \rho_{j}$

where $\rho_{\mathrm{j}}$ represent the autocorrelation of $\mathrm{r}_{\mathrm{t}}$ in order $\mathrm{j}$. The VR tests the null hypothesis that the $\mathrm{VR}=1$ for all $\mathrm{k}$. Then again, VR values that are greater than 1 suggest positive serial correlations, whereas values less than 1 mean negative serial correlations or mean reversions (Urquhart and McGroarty, 2016).

\subsection{BDS Test}

Linear tests may detect to fail nonlinear characteristics in the return data. BDS test is developed by Brock, Dechert and Schieinkman (1987) and provides evidence of a nonlinear dependence in stock return series. The null hypothesis of the test propose that the data generating process in the stock returns are independent and identically distributed (i.i.d.). The alternate hypothesis is that the model is misspecified (Brock et al., 1996). The BDS statistics is calculated as 
$W_{m, n}(\varepsilon)=\sqrt{n} \frac{T_{m, n}(\varepsilon)}{V_{m, n}(\varepsilon)}$

where $n$ denotes the sample size, $m$ the embedded dimension and $(\epsilon)$ the metric bound, which is the maximum difference between the observation pairs that are taken into consideration while calculating the correlation integral. $\mathrm{Tm}, \mathrm{n}(\varepsilon)$ is the difference between the dispersion of the observed data series in a number of spaces following an independent identical distribution (i.i.d.) process would generate in these spaces and has an asymptotic normal distribution with zero mean and variance $\mathrm{V}_{\mathrm{m}}^{2}(\varepsilon)$. The analysis of the observations in subsamples is a necessity, since BDS test can produce an unnecessary rejection of the null hypothesis, which states an assumption of i.i.d (Hsieh, 1991). The selection of $\varepsilon$ and $m$ is of crucial importance. Given that, the choice of too small values for $\varepsilon$ will capture very few points, thus following the prior literature $\varepsilon$ is a proportion of the standard deviation of the data. To assign the values for $\mathrm{m}$, again following the prior literature, we set the value equal to 2 to 5 , as the small sample properties of BDS test degrade as $m$ increases in value (Patterson and Ashley, 2000). The mean of the p-values produced from the values of $m$ is then calculated to uncover the predictability from the BDS test changes.

The literature points to the significance of whitening the returns through and ARGARCH process (Lim and Hooy, 2013); accordingly, this correction allows us to be certain that any remaining non-linear predictability is not associated to the conditional heteroscedasticity. Following Kim et al. (2011), Urquhart and McGroarty (2014), Urquhart and McGroarty (2016), we use a two-year moving sub-sample window to obtain measures of predictability. The test statistics is calculated using data from the first trading day in January 2002 to the last trading day in December 1991 and then move the window forward one-month to cover the period February 2002 to January 2004. This procedure allowed us to generate enough number of data to evaluate the predictability of returns over time.

\section{Data}

The data consists of the daily closing prices for Borsa Istanbul 100 (BIST 100) index, BIST 30 Index and BIST All Index for the period from 2002 to April 2019. Figure 1 shows the time plots of the three indices covered in the analysis. As it can be seen, BIST 30 have a higher value than the other two indices and BIST 100 and BIST All indices almost overlap each other. The daily return for each index is calculated by the following formula:

$r_{t}=\ln \left(P_{t}\right)-\ln \left(P_{t-1}\right)$

Table 2 presents the descriptive statistics of the daily returns of each index. The average return of the indices are very close to each other and the standard deviation of returns is almost similar. Still, BIST30 has the highest volatility. All of the series 
have a negative skewness implying a longer left tail. The high kurtosis measures for all three series indicate leptokurtic distributions which points to the non-normality in the return series at $1 \%$ statistical significance.

Figure 1. Time Plots of the BIST 30, BIST 100 and BIST All Index

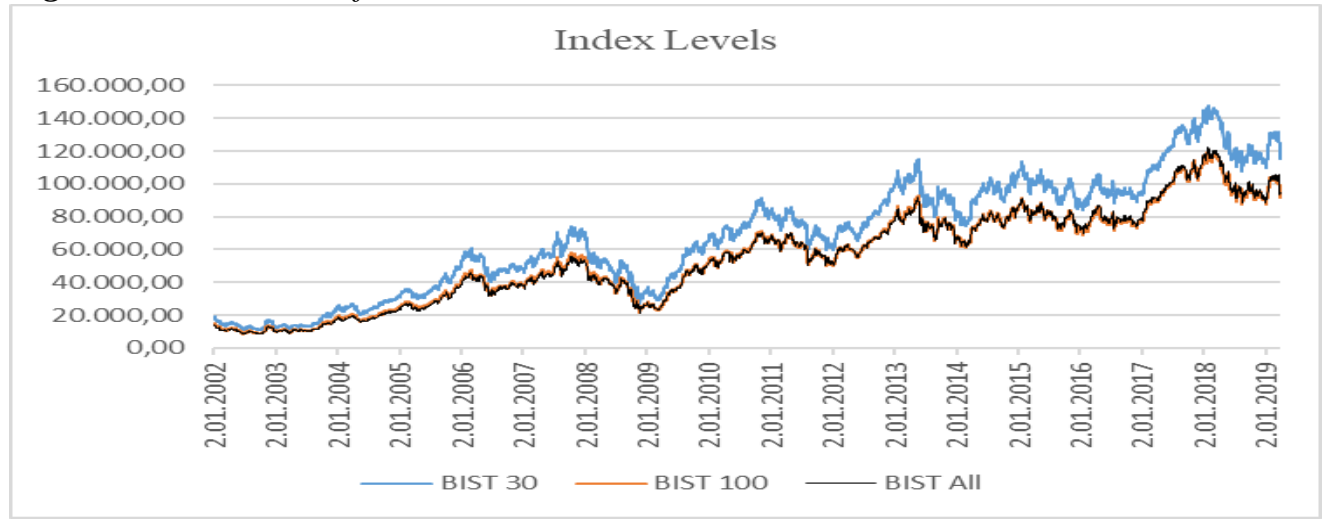

Table 2. Descriptive Statistics of the daily returns of the BIST 30, BIST 100 and BIST All

\begin{tabular}{lllllll}
\hline & Mean & Std, Dev, & Skewness & Kurtosis & Jarque-Bera & Observations \\
\hline BIST30 & 0,00043 & 0,0190 & $-0,05$ & 7,121811 & $3069,7 * * *$ & 4334 \\
BIST100 & 0,00043 & 0,0179 & $-0,16$ & 7,604082 & $3845,7 * * *$ & 4334 \\
BISTALL & 0,0004 & 0,0172 & $-0,22$ & 7,877432 & $4331,3 * * *$ & 4334 \\
\hline
\end{tabular}

Note: $* * *$ denotes statistical significance at $1 \%$.

Figure 2. Time Plots of the returns of BIST 30, BIST 100 and BIST All Index Returns of the Indices

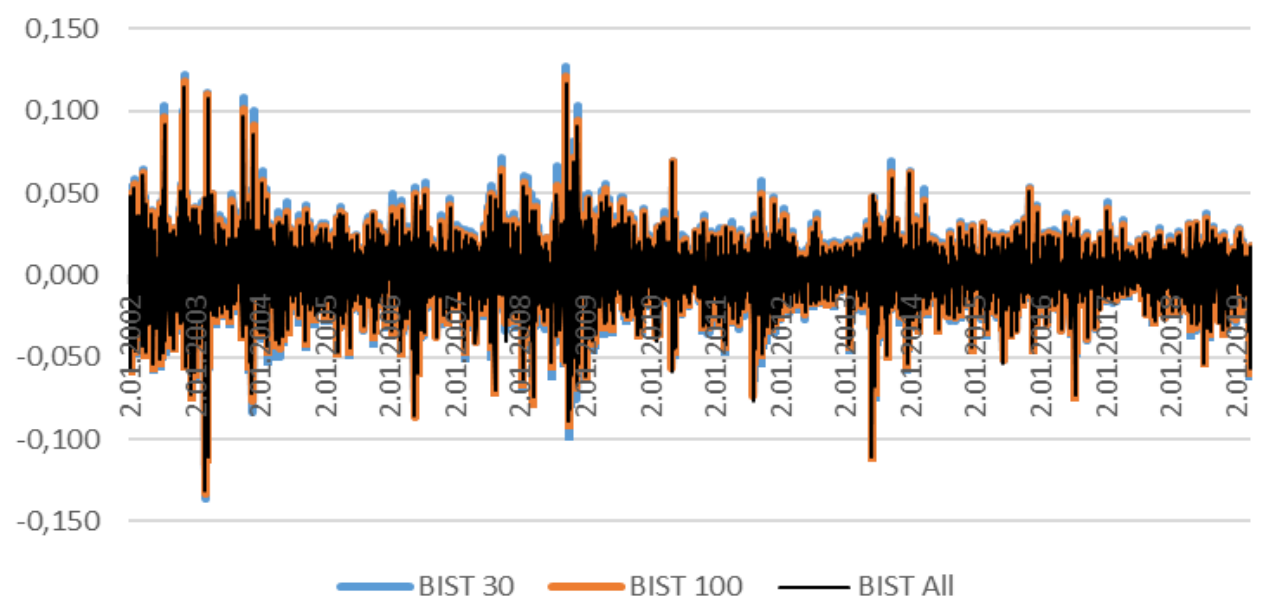




\section{Analysis Results}

The development of Variance Ratio Test values over time for the BIST-100 index is presented in Figure 3. The mean probability value of the test results was zero and the probability value was not observed to exceed the $95 \%$ confidence interval in any section of the studied period.

Figure 3. Variance Ratio Test for BIST-100

\section{BIST-100}

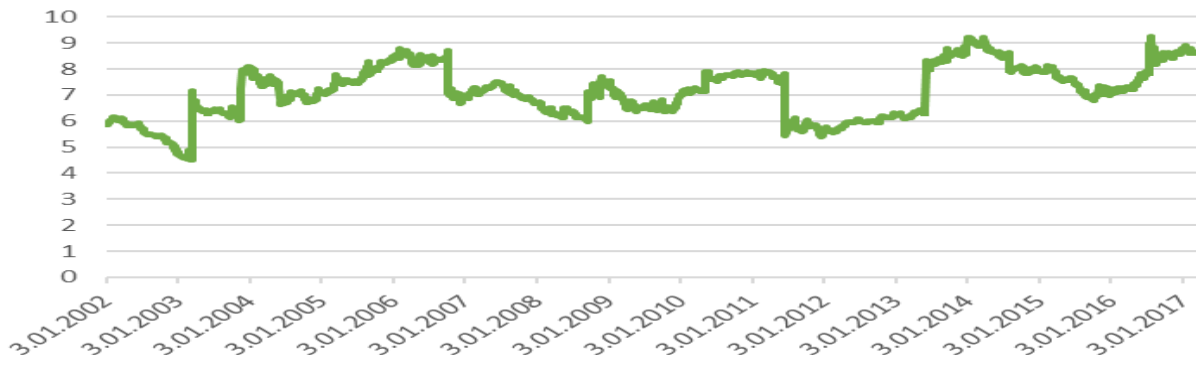

Table 3. VR Test Results

\begin{tabular}{llll}
\hline & BIST-30 & BIST-100 & BIST- National \\
\hline $2002-2003$ & 6.053742 & 5.907186 & 5.854572 \\
$2004-2005$ & 7.576585 & 7.438575 & 7.341923 \\
$2005-2006$ & 7.858813 & 7.585281 & 7.539539 \\
$2007-2009$ & 6.902991 & 6.612671 & 6.45111 \\
$2010-2011$ & 7.2285 & 7.106274 & 6.97471 \\
$2012-2013$ & 7.136664 & 6.709177 & 6.525677 \\
$2014-2015$ & 8.32169 & 7.929827 & 7.777232 \\
$2016-2017$ & 8.28359 & 8.095725 & 8.003723 \\
\hline
\end{tabular}

Figure 4 presents the values of the variance ratio test of the BIST-30 index. Looking at the graphs, the BIST-30 index shows lower variance values than BIST-100.

Figure 4. Variance Ratio Test for BIST-30

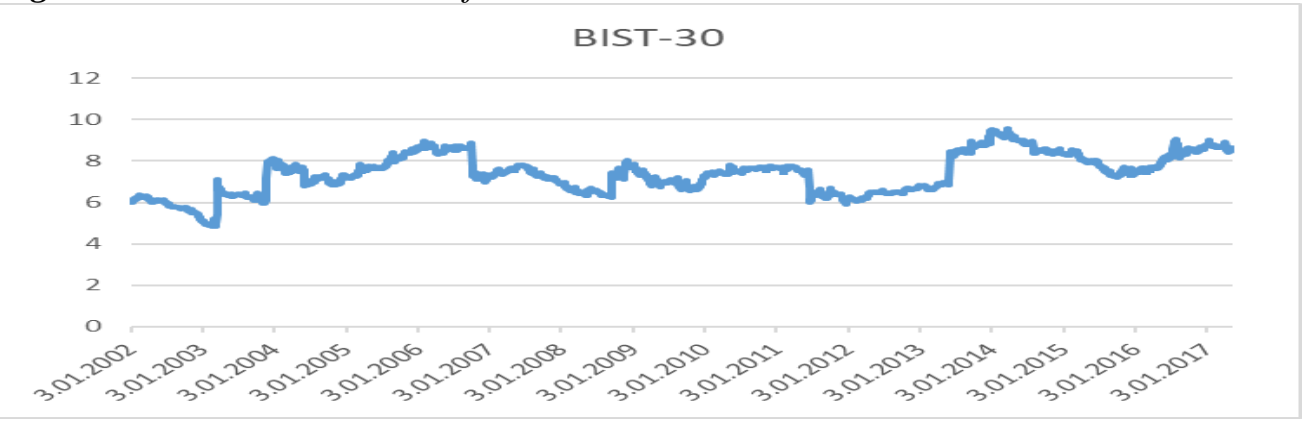


The Variance Ratio Test values of the BIST-Whole Index are shown in Figure 5. When compared with the other two indices, the values of this test are higher for BISTAll than the other two indices. Although not presented, the probability values of the analysis results were below $1 \%$ statistical significance level.

Figure 5. Variance Ratio Test for BIST-Whole

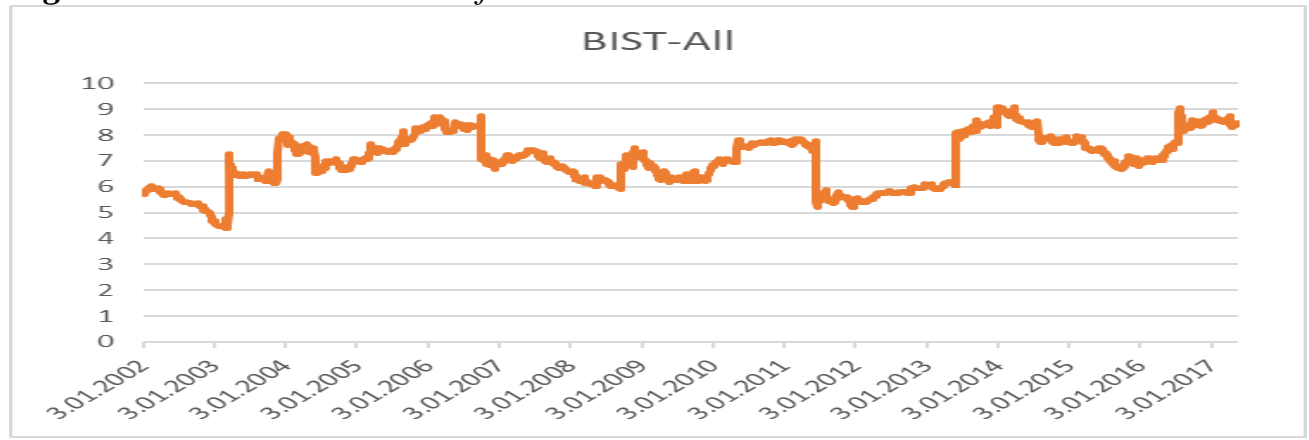

The BDS test is calculated taking into account the nonlinear characteristics of the data as mentioned in the previous section. Figure 6 presents the mean of the probability values of 2, 3, 4 and 5 dimensional BDS test statistics for BIST-100 Index. When the average of probability values is examined, these values have increased above $10 \%$ statistical significance level in the observations in 2003 and especially in the period between January 2013 and January 2017.

Table 4. BDS Test Results

\begin{tabular}{lllll}
\hline BIST 30 & & & \\
\hline & 2 lags & 3 lags & 4 lags & 5 lags \\
\hline $2002-2003$ & 0.070676 & 0.010113 & 0.009002 & 0.010274 \\
$2004-2005$ & 0.00778 & 0.00778 & 0.00778 & 0.00778 \\
$2005-2006$ & 0.024976 & 0.024976 & 0.024976 & 0.024976 \\
$2007-2009$ & 0.015291 & 0.015291 & 0.015291 & 0.015291 \\
$2010-2011$ & 0.011444 & 0.011444 & 0.011444 & 0.011444 \\
$2012-2013$ & 0.208627 & 0.208627 & 0.208627 & 0.208627 \\
$2014-2015$ & 0.432958 & 0.432958 & 0.432958 & 0.432958 \\
$2016-2017$ & 0.065801 & 0.065801 & 0.065801 & 0.065801 \\
\hline BIST 100 & & & & \\
\hline $2002-2003$ & 2 lags & 3 lags & 4 lags & 5 lags \\
$2004-2005$ & 0.050661 & 0.009686 & 0.009002 & 0.010237 \\
$2005-2006$ & 0.00171 & 0.00171 & 0.00171 & 0.00171 \\
$2007-2009$ & 0.009715 & 0.009715 & 0.009715 & 0.009715 \\
$2010-2011$ & 0.00824 & 0.00824 & 0.00824 & 0.00824 \\
$2012-2013$ & 0.009454 & 0.009454 & 0.009454 & 0.009454 \\
$2014-2015$ & 0.184883 & 0.184883 & 0.184883 & 0.184883 \\
$2016-2017$ & 0.406423 & 0.406423 & 0.406423 & 0.406423 \\
\hline
\end{tabular}




\begin{tabular}{lllll}
\hline BIST- National & \multicolumn{5}{l}{} \\
\hline & 2 lags & 3 lags & 4 lags & 5 lags \\
\hline $2002-2003$ & 0.029964 & 0.001738 & 0.000354 & $5.23 \mathrm{E}-05$ \\
$2004-2005$ & 0.000718 & 0.000718 & 0.000718 & 0.000718 \\
$2005-2006$ & 0.005651 & 0.005651 & 0.005651 & 0.005651 \\
$2007-2009$ & 0.008284 & 0.008284 & 0.008284 & 0.008284 \\
$2010-2011$ & 0.00687 & 0.00687 & 0.00687 & 0.00687 \\
$2012-2013$ & 0.159106 & 0.159106 & 0.159106 & 0.159106 \\
$2014-2015$ & 0.361364 & 0.361364 & 0.361364 & 0.361364 \\
$2016-2017$ & 0.051561 & 0.051561 & 0.051561 & 0.051561 \\
\hline
\end{tabular}

Figure 6. Mean BDS statistic probability values for BIST-100

\section{BIST 100}

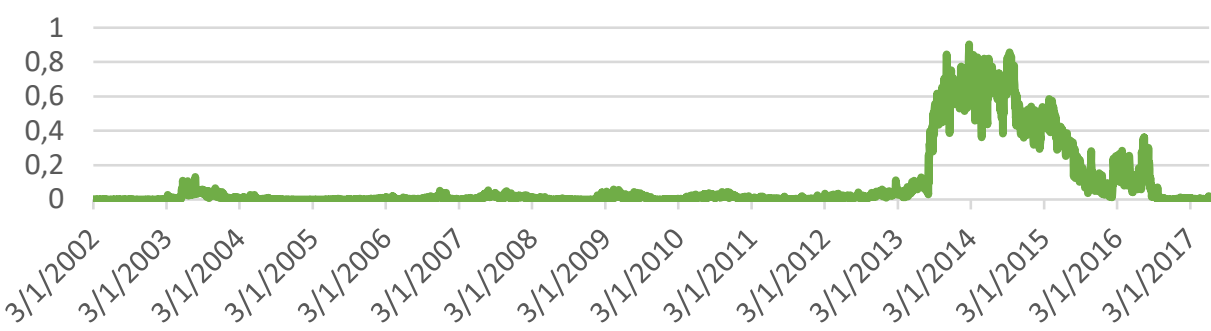

Figure 7 shows the mean of the probability values of the BDS test statistics for 2, 3, 4 and 5 dimensional BDS for BIST-30. Probability values for this index again remained outside the statistical significance level of $10 \%$ during 2003, for most observations between 2013 and 2016, and for small observations in 2009.

Figure 7. Probability values of Mean BDS Statistics for BIST-30

\section{BIST 30}

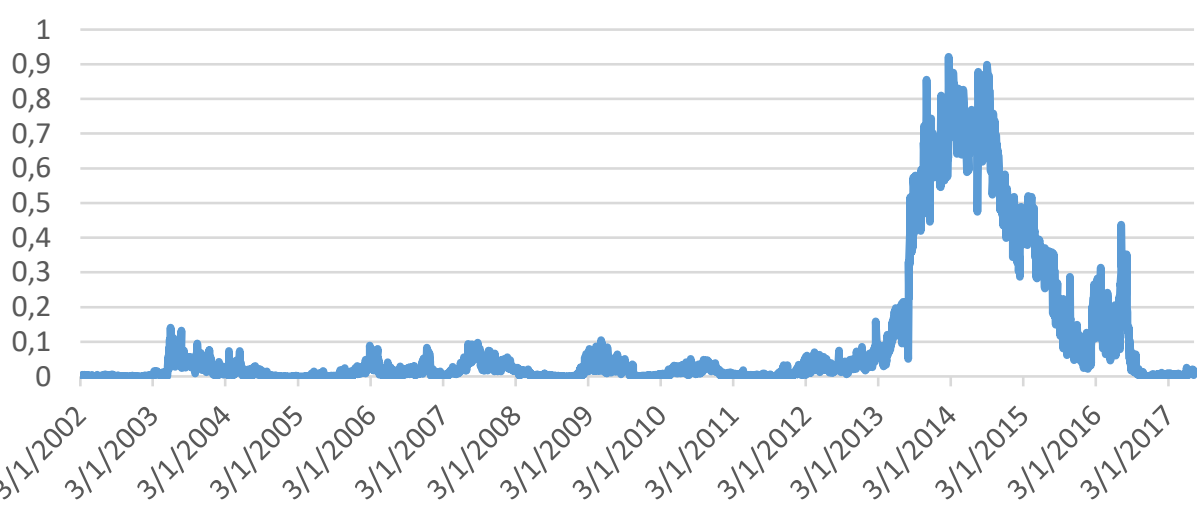


Finally, Figure 8 presents the mean of the probability values of BDS test statistics for 2, 3, 4 and 5 dimensions for BIST-All. Probability values for BIST-All exceeded the statistical significance level of 10\% between 2003 and 2014-2016 period.

Figure 8. Probability values of BDS-Average for all BDS Statistics

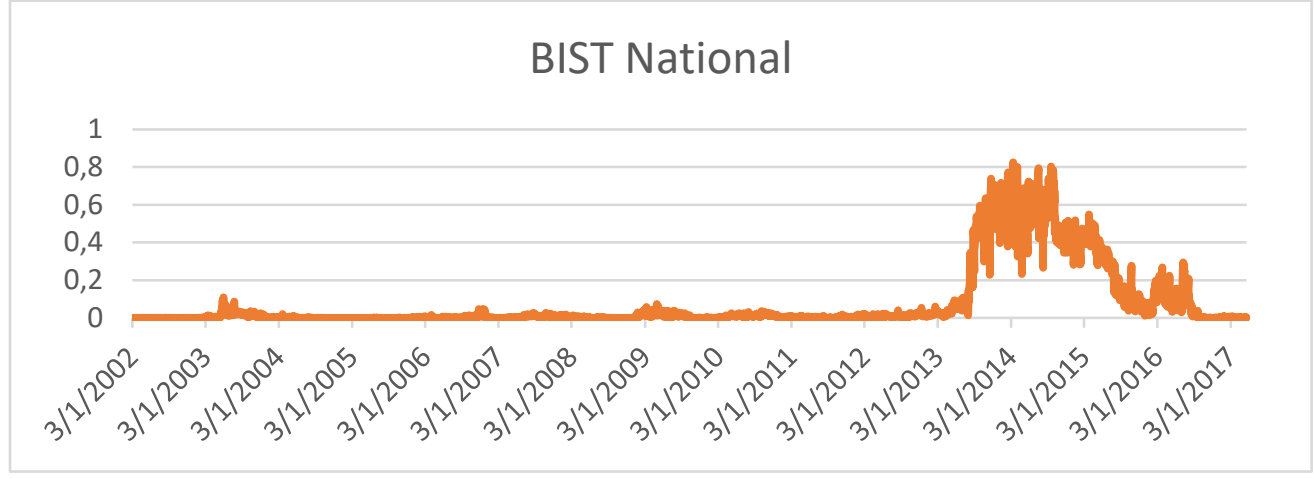

\section{Conclusions}

The Adaptive Market Hypothesis (AMH) suggests that market activity cannot consist of all or nothing, and that market activity and inefficiency can take place at the same time. The aim of this study is to investigate the existence of AMH in Borsa Istanbul (BIST). For this purpose, the series dependency of returns of BIST-100, BIST-30 and BIST-All indices, which are considered as the most important indicators for Borsa Istanbul for the period between January 2002 and April 2019, have been analyzed by linear and nonlinear methods.

According to the results of Variance Ratio Test which assumes that the data is linear, the probabilities of variance ratio tests for all three indices have been found to be statistically significant. In this test, no value has been found outside the statistical significance level. According to the Variance Ratio Test, Borsa Istanbul has a high predictability of return in this period. The absence of a change in statistical significance over time denies the existence of the AMH.

On the other hand, the probability values of the BDS Test Statistics, which examine the data in the absence of linearity approach, has gone beyond the statistical significance level especially in 2013-2017 period. This means that returns cannot be predicted in this period, and return series are independent of each other. This has been again observed in various observation periods. The results of the nonlinear tests coincide with those of Urquhart and Hudson (2013) and Hiremath and Narayan (2016). Considering our findings, it is possible to say that BIST indices function is parallel with the efficient market hypothesis. The difference between the BDS Test and the Variance Ratio Test is again due to the different calculations of the methods. When we look at the structure of the data it is noteworthy that it is far from linearity and it is suggested that the BDS Test is more appropriate to the structure of the data. 
The results indicate that the indices display market efficiency in various episodes and in other periods inefficiency is observed. These contrasting findings support the existence of $\mathrm{AMH}$ for the Borsa Istanbul indices under observation. In addition, the indices have different predictability levels in different periods. Although it is in the same market, predictability between indices has not always been parallel. As a result, it is concluded that Borsa İstanbul indices are not completely predictable. While the findings from some tests for yields are unpredictable, evidence has been found that the market is not weak form efficient. For future research, the analysis of predictability according to changing market conditions will also provide various implications for investors.

\section{References:}

Alvarez-Ramirez, J., Rodriguez, E. and Espinosa-Paredes, G. 2012. Is the US Stock Market Becoming Weakly Efficient Over Time? Evidence From 80-Year-Long Data. Physica A: Statistical Mechanics and its Applications, 391(22), 5643-5647.

Barberis, N. and Thaler, R. 2003. A Survey of Behavioral Finance, in Constantinides G.M., Harris M. and Stulz R.M. (Ed.), Handbook of Economics of Finance, Elsevier, US., 1053-1128.

Bodie, Z., Kane, A. and Marcus, A.J. 2014. Investments (10th Ed.), McGraw Hill, UK.

Brock, W.A., Dechert, W.D. and Schieinkman, J.A. 1987. A test for independence based on correlation dimension. SSRI working paper no. 8702. Madison, WI, Department of Economics, University of Wisconsin.

Brock, W.A., Dechert, W.D., Schieinkman, J.A. and LeBaron, B. 1996. A test for independence based on correlation dimension. Econometric Reviews, 15, 197-235.

Charles, A., Darné, O. and Kim, J.H. 2012. Exchange-Rate Return Predictability and The Adaptive Markets Hypothesis: Evidence from Major Foreign Exchange Rates. Journal of International Money and Finance, 31, 1607-1626

Choi, I. 1999. Testing the Random Walk Hypothesis for Real Exchange Rates. Journal of Applied Econometrics, 14(3), 293-308.

Dyakova, A. and Smith, G. 2013a. The Evolution of Stock Market Predictability in Bulgaria. Applied Financial Economics, 23(9), 8005-8816.

Dyakova, A. and Smith, G. 2013b. Bulgarian Stock Market Relative Predictability: BSESofia Stocks and South East European Markets. Applied Financial Economics, 23 (15), 1257-1271.

Ertas F.C. and Özkan, O. 2018. Piyasa Etkinliği Açısından Adaptif Piyasa Hipotezi’nin Test Edilmesi: Türkiye ve ABD Hisse Senedi Piyasaları Örneği. Finans Politik ve Ekonomik Yorumlar, 642, 23-40.

Escanciano, J.C. and Lobato, I.N. 2009. An Automatic Portmanteau Test for Serial Correlation. Journal of Econometrics, 151(2), 140-149.

Escanciano, J.C. and Velasco, C. 2006. Generalized Spectral Tests for The Martingale Difference Hypothesis. Journal of Econometrics, 134(1), 151-185.

Fama, E.F. 1970. Efficient Capital Markets: A Review of Theory and Empirical Work. The Journal of Finance, 25(2), 383-417.

Hiremath, G.S. and Narayan, S. 2016. Testing the Adaptive Market Hypothesis and Its Determinants for The Indian Stock Markets. Finance Research Letters, 19, 173-180.

Hsieh, D.A. 1991. Chaos and nonlinear dynamics: Application to financial markets. Journal of Finance, 46, 488-502. 
Hull, M. and McGroarty, F. 2014. Do Emerging Markets Become More Efficient as They Develop? Long Memory Persistence in Equity Indices. Emerging Markets Review, $18,45-61$.

Gyamfi, E.N. 2018. Adaptive Market Hypothesis: Evidence from the Ghanaian Stock Market. Journal of African Business, 19(2), 195-209.

Ghazani, M.M. and Araghi, M.K. 2014. Evaluation of The Adaptive Market Hypothesis as an Evolutionary Perspective on Market Efficiency: Evidence From the Tehran Stock Exchange. Research in International Business and Finance, 32, 50-59.

Ghazani, M.M. and Ebrahimi, S.B. 2019. Testing the Adaptive Market Hypothesis as an Evolutionary Perspective on Market Efficiency: Evidence from the Crude Oil Prices, Finance Research Letters, doi: https://doi.org/10.1016/j.frl.2019.03.032.

Grossman, S.J. and Stiglitz, J.E. 1980. On the Impossibility of Informationally Efficient Markets. The American Economic Review, 70(3), 393-408.

Hiremath, G.S. and Kumari, J. 2014. Stock Returns Predictability and The Adaptive Market Hypothesis in Emerging Markets: Evidence from India. Available at: http://www.springerplus.com/content/3/1/428.

Hiremath, G.S. and Narayan, S. 2016. Testing the Adaptive Market Hypothesis and Its Determinants for the Indian Stock Markets. Finance Research Letters, 19, 173-180.

Ito, M., Noda, A. and Wada, T. 2014. International Stock Market Efficiency: A NonBayesian Time-Varying Model Approach. Applied Economics, 46(23), 2744-2754.

Ito, M., Noda, A. and Wada, T. 2016. The Evolution of Stock Market Efficiency in the US: A Non-Bayesian Time-Varying Model Approach. Applied Economics, 48(7), 621-635.

Ito, M. and Sugiyama, S. 2009. Measuring the Degree of Time Varying Market Inefficiency. Economics Letters, 103(1), 62-64.

Kim, J.H., Shamsuddin, A. and Lim, K. 2011. Stock Return Predictability and the Adaptive Markets Hypothesis: Evidence from Century-Long U.S. Data. Journal of Empirical Finance, 18, 868-879.

Khuntia, S. and Pattanayak, J.K. 2018. Adaptive Market Hypothesis and Evolving Predictability of Bitcoin. Economics Letters, 167, 26-28.

Lim, K.P. 2007. Ranking Market Efficiency for Stock Markets: A Nonlinear Perspective. Physica A, 376, 445-454.

Lim, K.P. and Brooks, R.D. 2006. The Evolving and Relative Efficiencies Of Stock Markets: Empirical Evidence From Rolling Bicorrelation Test Statistics. SSRN working paper. Available at: http://ssrn.com/abstract=931071.

Lim, K.P. and Brooks, R. 2011. The Evolution of Stock Market Efficiency over Time: A Survey of the Empirical Literature. Journal of Economics Survey, 25(1), 69-108.

Lim, K.P., Luo, W. and Kim, J.H. 2013. Are US Stock Index Returns Predictable? Evidence from Automatic Autocorrelation-Based Tests. Applied Economics, 45(8), 953-962.

Lo, A.W., MacKinlay, A.C. 1988. Stock market prices do not follow random walks: evidence from a simple specification test. Review of Financial Studies, 1(1), 41-66.

Lo, A.W. 2004. The Adaptive Markets Hypothesis. Journal of Portfolio Management, 30, 15 29.

Lo, A.W. 2005. Reconciling Efficient Markets with Behavioral Finance: The Adaptive Markets Hypothesis. Journal of Investment Consulting, 7(2), 21-44.

Neely, C.J., Weller, P.A. and Ulrich, J.M. 2009. The Adaptive Markets Hypothesis: Evidence from the Foreign Exchange Market. The Journal of Financial and Quantitative Analysis, 44(2), 467-488.

Niemczak, K. and Smith, G. 2013. Middle Eastern Stock Markets: Absolute, Evolving and Relative Efficiency. Applied Financial Economics, 23(3), 181-198. 
Noda, A. 2016. A Test of the Adaptive Market Hypothesis Using A Time-Varying AR Model In Japan. Finance Research Letters, 17, 66-71.

Patterson, D.M., and Ashley, R.A. 2000. A nonlinear time series workshop: A toolkit for detecting and identifying nonlinear serial dependence. Boston, MA: Kluwer Academic.

Popović, S., Mugoša, A. and Đurović, A. 2013. Adaptive Markets Hypothesis: Empirical Evidence from Montenegro Equity Market. Economic Research, 26(3), 31-46.

Rodriguez, E., Aguilar-Cornejo, M. and Alvarez-Ramirez, J. 2014. US Stock Market Efficiency over Weekly, Monthly, Quarterly and Yearly Time Scales. Physica A: Statistical Mechanics and Its Applications, 413, 554-564.

Self, J.K. and Mathur, I. 2006. Asymmetric Stationarity in National Stock Market Indices: An MTAR Analysis. Journal of Business, 79(6), 3153-3174.

Shleifer, A. 2000. Inefficient Markets. Oxford University Press, NY.

Smith, G. 2012. The Changing and Relative Efficiency of European Emerging Stock Markets. The European Journal of Finance, 18(8), 689-708.

Smith, G. and Dyakova, A. 2014. African Stock Markets: Efficiency and Relative Predictability. South African Journal of Economics, 82(2), 258-275.

Todea, A., Ulici, M. and Silaghi, S. 2009. Adaptive Market Hypothesis: Evidence from AsiaPacific Financial Markets. The Review of Finance and Banking, 1(1), 7-13.

Thalassinos, I.E., Stamatopoulos, D.T. and Thalassinos, E.P. 2015. The European Sovereign Debt Crisis and the Role of Credit Swaps. Chapter book in The WSPC Handbook of Futures Markets (eds) W. T. Ziemba and A.G. Malliaris, in memory of Late Milton Miller (Nobel 1990) World Scientific Handbook in Financial Economic Series Vol. 5, Chapter 20, pp. 605-639, ISBN: 978-981-4566-91-9, (doi: 10.1142/9789814566926_0020).

Urquhart, A. and Hudson, R. 2013. Efficient or Adaptive Markets? Evidence from Major Stock Markets Using Very Long Run Historic Data. International Review of Financial Analysis, 28, 130-142.

Urquhart, A. \&McGroarty, F. 2014. Calendar effects,market conditions and the adaptive market hypothesis: Evidence from long-run U.S. data. International Review of Financial Analysis, 35, 154-166.

Urquhart, A., Gebka, B. and Hudson, R. 2015. How Exactly Do Markets Adapt? Evidence from the Moving Average Rule in Three Developed Markets. Journal of International Financial Markets Institutions and Money, 38, 127-147.

Urquhart, A. and McGroarty, F. 2016. Are Stock Markets Really Efficient? Evidence of the Adaptive Market Hypothesis. International Review of Financial Analysis, 47, 39-49.

Zhou, J. and Lee, J.M. 2013. Adaptive Market Hypothesis: Evidence from the REIT Market. Applied Financial Economics, 23(21), 1649-1662. 